\title{
Tax Havens: A Global Issue
}

\author{
Harmanpreet Kaur*
}

\begin{abstract}
In recent years, tax havens have attracted increasing attention of many international organisations, policy makers and development agencies. This article deals with concept of tax havens and their impact on different countries. Tax havens are the countries which offer very low tax rates to foreign investors and ensure very high level of secrecy for their transactions. This paper is an attempt to discuss seminal work on tax havens, its characteristics, positive and negative aspects of these states as examined by various researchers. The impact of tax havens on India and initiatives taken by OECD against these harmful tax practices have also been discussed.
\end{abstract}

Keywords: Tax havens, Investments, Economic growth.

\subsection{Tax Havens: An Introduction}

Globalization has led to greater integration and interdependence of global economies. In recent years, the international mobility of corporate activity has increased due to the process of globalisation. Thus, it has resulted in erosion of business boundaries. Removal of trade barriers has increased capital flows among countries. As more mobile capital is available, many countries want to attract investors. Taxation has become an important factor in attracting investments. Countries which are keen to attract foreign capital face significant international pressure to abate their tax on income earned by foreign investors.

Since minimisation of taxation of foreign investors has led to budgetary and policy compromises, not all countries want to entice foreign investment in this manner. The countries known as "tax havens" offer very low tax rates and other tax features to attract foreign investors. Tax havens are the countries which offer themselves to be used as off shore financial centers, having high level of secrecy and good infrastructure.

*Research Scholar, Department of Commerce, Delhi School of Economics, University of Delhi. 
There is no generally established meaning of a tax haven; there are some practices that create a tax haven. There are roughly 50 major tax havens in the world today (see Appendix I). The Organization for Economic Cooperation and Development (OECD) provides key factors to identify tax havens, in its 1998 Report on Harmful Tax Competition: An Emerging Global Issue. The key factors that are used to identify tax havens are as follows:

- No or only nominal taxes: No or only nominal taxation on the relevant income is the starting point to classify a jurisdiction as a tax haven and whether it offers itself, or is perceived to offer itself, as a place to be used by non-residents to escape tax in their country of residence.

- Lack of effective exchange of information: Tax havens typically have in place laws or administrative practices under which businesses and individuals can benefit from strict secrecy rules and other protections against scrutiny by tax authorities thereby preventing the effective exchange of information on taxpayers benefiting from the low tax jurisdiction.

- Lack of transparency: A lack of transparency in the operation of the legislative, legal or administrative provisions is another factor in identifying tax havens.

- No substantial activities: The absence of a requirement that the activity be substantial is important since it would suggest that a jurisdiction may be attempting to attract investment or transactions that are purely tax driven."

- The lack of transparency and lack of effective exchange of information on tax matters is the main issue of international concern.

\subsection{Tax havens and tax competition}

The presence of tax havens creates both problems and opportunities for other countries. Tax havens are seen with distress in parts of the high tax world. Corporate tax bases in the high-industrialised countries are exhausted because of the augmented movement of goods and services, so tax revenues are declining and a competition among governments is increasing. Countries in their quest to attract and hold mobile investment and the accompanying tax revenues may be tempted to reduce tax rates. Thus, it can lead to a 'race to the bottom' lashing corporate tax rates below the efficient levels and under provision of public goods.

\subsection{Tax havens and Tax avoidance}

Tax havens are used by multinational firms for avoiding taxes that would else be payable to government of other nations. Multinationals can reduce or postpone their tax 
liabilities and choice depending on how government taxes the income of their resident companies from abroad. It is advantageous to relocate income from high tax (home) country to tax havens, under territorial system (used by capital exporting countriesGermany) which exempts foreign income from taxation. Under world-wide taxation system that taxes foreign income and provides credit for taxes paid to foreign government, deferral of income until it is repatriated is more suitable. By delaying repatriations present value of tax liability can be reduced. The multinationals corporations can arrange an array of transactions - royalty payments, dividend repatriations, intra-firm lending and transfer price for within-firm international transactions, with a motive to reduce their total tax obligations.

\subsection{Impact of tax havens on investment}

Tax havens attract both foreign direct investment and portfolio investment. "Tax haven economies now account for a non-negligible and increasing share of global FDI flows, at about 6\%," (World Investment Report,2013). FDI flows to such offshore tax havens (offshore financial Centre's, OFC) have rose, escalating to US\$75-billion per year in 2007-2012 from an average of US\$15-billion in 2000-2006, the Report said (Figure 1). The problem of round tripping has emerged due to presence of tax havens.

Figure 1: Value and share of offshore tax havens in global FDI flows, 1990-2012. (billions of dollars and percent)

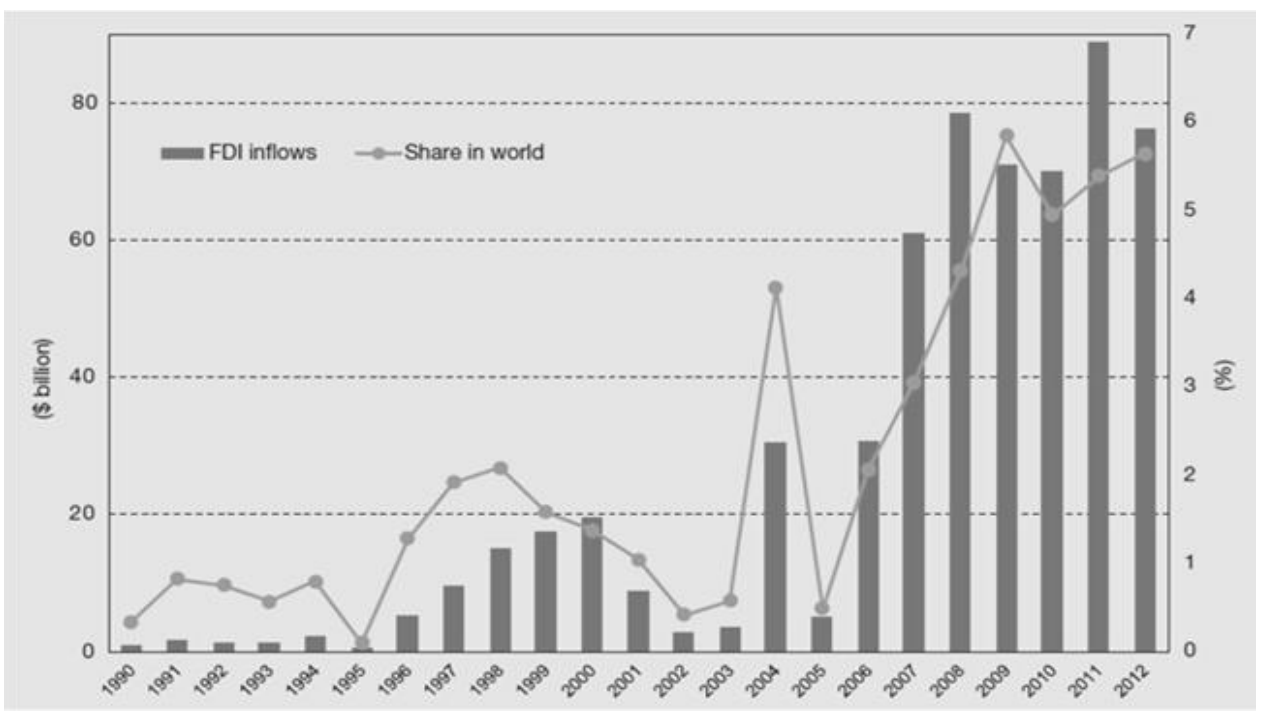

Source: UNCTAD, World Investment Report, 2013 
Round tripping means investing back in one's own country by routing investment through another country. Thus, tax havens are used as conduit of investments to avoid taxes. Even more money is directed through 'special purpose entities' (SPEs), set up for enabling investment or for some specific purposes.

\subsection{Structure of the paper}

The rest of the paper is organised as follows. Section two lays down the objectives of the study. Section three of the paper reviews theoretical and empirical literature on tax havens and its repercussions for worldwide investment and tax policies of the countries in the world. Section four depicts the OECD work on tax havens. Section five depicts impact of tax havens on India and section six concludes.

\subsection{Objective of the study}

The objectives of the study are as follows:

- To review literature on tax havens.

- To understand the ways in which multinational firms use tax havens.

- To study the impact of tax havens on investments and economic growth of non-tax haven countries.

\subsection{Review of Literature}

This section reviews the various theoretical and empirical papers on tax havens. Slemrod and Wilson (2006) have developed a tax competition model and tax havens are envisaged as 'parasitic' on the tax bases of non-havens. They show how the supply curve of tax havens should slope up. Tax havens 'sell protection from national taxation' or offer 'concealment services' for avoiding home country taxes. Non-tax haven countries also incur costs (enforcement cost) to restrict the relocation of taxable earnings to tax havens, in addition to cost incurred by havens to provide concealment services. They use up real resources to avoid taxes. Thus, it leads to wasteful expenditure of resources. The cost of becoming tax haven increases with size but benefits remain same so small countries choses to become tax havens. Tax havens forces non-tax haven countries to reduce tax rates and thus intensify tax competition, which ultimately reduces supply of public goods. If small number of large tax havens is reduced, all countries would be better off. In addition to this, if enforcement levels are reduced with increasing statutory tax rates, demand for tax evasion facilities by tax havens would increase and effective price of these services would increase thereby discouraging evasion. 
Keen (2001) does not focus clearly on tax bases however, on preferential tax regimens for foreign investors or certain sectors. He used inter-jurisdictional tax competition stylized model over distinctive tax bases and introduces the assumption that both tax bases are fixed in total amount and are independent of each other (i.e. tax on the other, does not affect the location of each). If preferential regimens are existent, it is possible to limit tax competition to specific portions of tax system by competing only for mobile tax bases (capital) while charging high tax rates on immobile tax bases (capital). In contrast, if preferential tax regimes are absent, single tax rate is applied on all tax bases competing for both mobile and immobile tax bases (capital). Thus, elimination of preferential tax regimes intensifies tax competition.

Hong and Smart (2007) developed two sector (domestic and multinational) corporate income taxation general equilibrium model to examine the impact of international tax planning on corporate tax bases and investment. In the model, corporate tax is levied on both the returns on inward FDI and earnings of domestic entrepreneurs. The wages of domestic workers decreases due to taxation of mobile capital but government seeks to redistribute revenues from taxing both inward FDI and domestic entrepreneurs. FDI should be subsidized to increase wages when a higher tax rate tends to deter FDI and thus in effect lower wages. The effective tax rates faced by MNC's are reduced by tax planning (avoidance) and thus, MNC's are ready to invest in non-havens for any given statutory tax rate. Thus, international tax planning allows countries to prevent outflow of FDI, even if corporate income tax is high. Tax planning makes location of real business less receptive to differences in tax rates. Some sort of restriction is required on tax planning (thin capitalization) to improve welfare.

Chu, Lai and Cheng (2014) study how the economic growth rate and social welfare in high tax countries are affected by presence of tax havens. They develop a general equilibrium model including endogenous growth and tax havens incorporating imperfect competition, having positive externality on the production sector as government services are financed by tax revenues. The existence of tax havens affects the growth rate of high tax countries in two opposing ways, and two relative forces determine the overall growth rate. First, tax havens lessen tax revenues and thus, shrink the government infrastructure expenditure, which in turn dampen economic growth rate (namely, public investment effect). Second, tax-planning prospects provided by tax havens reduce marginal cost of capital and boosts growth, as more inducements are available to accumulate capital (namely, tax planning effect). The tax havens enhance social welfare if government expenditure share in production is low or initial income tax rate is high. If we consider market structure to depict welfare effect of tax havens, perfect competition and no 
production externalities improve welfare. In the presence of tax havens, a tax rate under welfare-maximizing scheme is lower than that of growth maximizing tax rate.

Dharmapala and Hines (2006) describe a set of features of the tax haven jurisdictions. They are small countries and also small in population size (most likely to be less than 1 million). They tend to be open economies; nearby major capital exporters, mostly islands \& have larger proportion of population living near costal area. They have good communication infrastructure (as measured by no. of telephone lines), poorly endowed with natural resources (as measured by subsoil assets per capita). They tend to have English as their official language, are of British legal origin and political system is parliamentary rather than presidential system. They are most probably sovereign states (as stated by lower rate of UN membership). Tax havens draw substantial foreign investments due to low tax rates and prospects for tax avoidance so are more prosperous than other countries. The main focus of this paper is to empirically find out that countries with better governance turn out to be tax havens. DH use overall measure of governance institutions which measures the numerous aspects of governance quality comprising voice and accountability (VA), political stability (PS), government effectiveness (GE), rule of law (RL) and control of corruption (CC). DH finds that in comparison to nonhaven countries tax havens scored better on this measure, because expected benefits of higher investment flows and economic benefits that accompany them, tends to tax reductions in well governed countries than in poorly governed countries. Probit, logit and linear probability (including non-parametric matching estimation) models all give consistent results. In particular, better governed countries become tax havens because of their tax policy choices and because they can oblige not to confiscate foreign investors. Better governed countries incline to have lower statutory tax rates.

Desai, Foley and Hines (2004) provide substantiation that tax haven operations boost economic activity in non-haven countries within same regions implying complementary relationship between haven and non-haven activities. They use an affiliate-level panel data of American multinationals from 1982 through 1999 on the financial and operating features of U.S. firms functioning abroad. Analysis of this data specifies that taxable income of American multinationals relocated by them from high tax to low tax country using tax havens and also postpone home country taxes on foreign earnings. The Logit and Tobit regression model is used to identify the features of multinational parents that are linked with tax havens. Tax haven operations are set up most probably by large firms. Firms with larger foreign operations, which have high portion of sales to related parties abroad (intra firm trade) and more technology- incentive (R\&D sales) corporations have tax haven affiliates. Firms whose non- haven affiliates are situated in low tax jurisdictions takes the benefit of deferral of home country taxation by 
establishing tax haven affiliate. This analysis makes a distinction between more populated tax haven countries (Big 7) from small tax haven countries. Big 7 countries are tax haven countries with population above 1 million. Big 7 countries have high concentration of tax haven activities if firms outside of tax havens face high foreign tax rates and prefer to relocate income to Big 7 countries through transfer pricing. Another measure used was affiliate leverage (tax deductibility of interest payments).

Instrumental Variable Analysis is used to identify link between haven and non-haven activities by using GDP growth rates as instruments for non-haven growth rates. They evaluate the effect of non-tax haven activities on operations of tax havens, as data is readily available for non-havens and made inferences about effect of tax havens activities on non- tax havens. The annual growth rate of sales and regional property, plant and equipment (PPE) for multinational parents outside tax havens are used as dependent variables in regression analysis. The Europe, Latin America and Other Western Hemisphere, Asia/Pacific, Africa, and the Middle East are the five regions considered. Sales growth and Net PPE growth of non-havens indicates that the demand for tax haven activities increases when activities outside of tax haven increases. The result also indicates that firms are more likely to use tax haven affiliates if they are initially situated in countries that grew rapidly. Because of symmetry, this complementary relationship indicates economic activity among foreign affiliates outside tax havens increases due to the acquisition of tax haven. The results indicates use of tax havens do not divert economic activity contrary to the tax competition literature.

Hines and Rice (1990) analyse the origin of tax havens and their impact on US and foreign governments. They also examine how US firms use the incentives created by low tax rates of tax havens in the year 1982. They identify 41 tax havens for US businesses. To estimate scale of business operations: they use gross assets, equity and income of US firms in havens (financial activity) and for physical activity use employment and plant, property and equipment (PPE) of US corporates' foreign affiliates. They distinguish between small tax havens (called Dots) and large tax havens (Big 7) as their economics differ significantly. Together Big 7 countries with population exceeding 1 million and account for $89 \%$ of tax haven GDP. Tax havens offer two advantages to US corporate tax payers: while calculating foreign tax credit, foreign income is raised because of earnings in the tax havens and by delaying repatriations of profits firms can earn interest on their residual US tax liability. The devices used for moving taxable income are intra firm lending (finance firms in high tax countries with debt), transfer pricing and factoring income and other exports.

They use OLS estimates and then use instrumental variable analysis (to capture tax rate endogeneity), instrument used for its tax rate is log of host country population. As 
assessed by reported income, US firms locate substantial part of their foreign activity in tax havens. Both financial and non-financial earnings of tax haven affiliates are considered when link between low tax rate and abnormally high profits is being established. The local employment of labour and capital is inversely related with tax rates. The revenue inferences for the US are complex, the US government ability to tax the foreign earnings of American firms is enhanced due to presence of tax havens. As foreign tax credits obtainable on foreign income earned in havens are low as compared to other countries, US government gains from haven activities. The foreign tax credits rises when tax havens increases tax rates and thus, negatively affects US government.

Hines (2005) reviews how international businesses use tax havens, and impact of their tax structures on economic consequences in tax haven countries and elsewhere. Foreign investments are enticed to tax havens for motives beyond the after tax return to local activities, as they also use tax have ns to dodge taxes. In his sample of year 1999, although less than $1 \%$ of world's population is located in tax havens, over $8 \%$ of the plant, property and equipment (PPE) held overseas by American multinationals is located there and over $5.7 \%$ of foreign employment. Approximately $2.3 \%$ of total world product (excluding U.S.) is contributed by tax haven economies. The data on financial variables (gross foreign assets, sales, income) revealed concentration of financial activity in tax havens. The data obtained from Penn World Tables over the period of 1982-1999 about annual real per capita economic growth rates reveals that tax havens grew at an average annual rate of $3.3 \%$ which compares well to the world average of $1.4 \%$. The results indicated that multinational firms pay significant income taxes and employ workers in tax havens in comparison to other countries. The government funds (public sectors) of tax havens are not negatively affected by giving tax incentives to foreign investors (ratio of government product, government spending and tax revenue to GDP are used as provided Penn World Table and IMF). Thus, all results indicate that tax haven countries have prospered since 1982 and will continue to play important role.

Hines (2010) evaluates economic effects of tax havens on international investment flows, FDI, capital markets, and economic growth patterns of tax havens. Tax havens obtain large capital flows (direct and portfolio investment) from other countries. The data for 2007 shows that level of inbound portfolio investment in tax havens is far out of proportion to their GDP's and population. Proximity to tax haven and economy size of a source country strongly influences capital flows. Tax havens also attract large direct investment from high tax countries (USA) and employment than their small economic size would originally permit. The financial markets are improved with presence of tax havens (reduce monopoly) as they compete with financial operations in nearby countries. The facts indicate that tax havens boost investments in high tax countries and eventually 
lead to economic growth elsewhere in the world. As far as economic growth rates are concerned, between 1992 and 2006, per capita real annual economic growth rate of different countries shows that countries nearer to tax havens shows more rapid economic growth and tax havens demonstrate faster economic growth $(2.85 \%)$ than other countries.

Blanco and Rogers (2011) examines how FDI and number of American affiliates in a tax haven are affected by propinquity to nearest tax haven. They use panel data of annual FDI for a sample of 18 tax havens between 1991 and 2005 (UNCTAD) and annual observations of American MNCs in tax havens during period 1999-2005 for 19 countries. Natural log of annual FDI inflows and natural log of no. of affiliates of American MNCs are used as dependent variables. Natural log of population, openness, exchange rate, initial level of GDP per capita are control variables. The inverse of the natural logarithm of the distance to the nearest tax haven is used as tax haven proximity variable. Other variables are natural log of FDI inflows and no. of American affiliates in nearest tax havens. A fixed effect of time is also considered. Spatial Error Model estimates are considered over OLS estimates as it removes all the potential bias of spatially correlated errors. The results indicate that distance to the nearest tax haven has positive relationship with FDI inflows and no. of American affiliates. Tax havens compete harmfully for mobile capital and geographic location relative to others. They also find an evidence of agglomeration and spillover effects with regard to location of American affiliates and also investigate location decision of top 500 American firms (Forbes 500). The firms are more likely to expand operations in a nearby tax haven, provided a firm is previously situated in a tax haven. Tax havens also benefits from being closer to other tax havens with high presence affiliates. Thus, tax havens want to attract affiliates in nearby havens by marketing it well and target specific sectors to take benefit of the agglomeration effect.

Blanco and Rogers (2014) examines the effect of tax haven countries on non-tax haven countries in terms of FDI with special focus on developing countries. They use panel data for period 1990-2008 of 142 non-tax haven countries, including 108 developing and 34 developed countries. They lay emphasis on agglomeration effects by including FDI inflows levels in tax havens and by evaluating proximity to the nearest tax haven encapsulate geographic spillovers. Control variables in the analysis are initial GDP, trade openness, population, exchange rate, fiscal freedom and British legal origin. The landlocked dummy variable and a series of regional dummy variables for Africa, America, Asia, Europe, and Pacific are included to depict geographic conditions. The ordinary least square (OLS) model is used first. The result indicates positive spillover effects of FDI inflows in tax havens especially on neighbouring developing countries, 
not on developed countries. They use balanced panel framework by restricting its sample to 94 developing countries between 1995 and 2007 period to explore further the role of geography. The endogeneity of tax haven FDI is taken care of by using various tests. They use balanced panel framework with spatial considerations to further find out the geographic spillover effects of tax haven FDI inflows on developing countries. Developing countries which are located nearby to tax havens benefits most as compared to farther ones. They inspect spatial interdependence of FDI. Spatial error and lag models tackle any autocorrelation and gives consistent results. Developing countries should develop polices to take benefit of spillovers as tax havens have positive impact on nearby developing countries.

Gumpert, Hines and Schnitzer (2011) examine investment patterns of multinational firms subject to a tax exemption system on foreign income, in tax havens. They develop a stylized theoretical framework identifying that high non-haven tax rates encourage tax haven investments but firm- specific marginal cost of income reallocation, dampen this effect. They separately study the tax haven investments of manufacturing and service companies. They use an affiliate level panel data of German multinationals for the period 2002-2008 of outward FDI using different ways to estimate regression equation: linear probability model, pooled linear probability model, pooled linear instrumental variable model, linear fixed effects model and linear fixed effects model with instrumental variables. The firm level foreign tax rates at non-haven locations are depicted through average foreign non-haven tax rate (instrument). The model shows the relationship between non-tax haven tax rate and investment in tax haven in two ways: the probability of investing in a tax haven increases with higher tax rates in countries where firm is previously located before investing in tax haven and opposite relationship, where tax havens attractiveness intensifies as tax rates fall in prospective investment location. The results show manufacturing firms most probably invest in tax havens as tax rate increases in foreign non-haven locations, even after considering unobservable differences in marginal cost of reallocating income. Investment in tax havens by the service sector is not significantly affected by taxation if observable differences are taken into account. Service firms face high cost of reallocating income and uniformity of profit allocation cost among service firms. The service firms are located in tax havens because of low cost of establishing affiliate and earning from ordinary course of business there.

\subsection{The OECD Initiative and its Consequences for Tax Havens}

In 1998, the OECD published its report Harmful Tax Competition: An Emerging Global Issue (1998 Report). The main focus of this project was to discourage from 
pursuing tax policies that would harm other countries by unjustly eroding tax bases by OECD member and some non- member countries, which alters trade and investment patterns and undermine fairness and objectivity of tax systems by affecting the location of financial and other service activities. In this report, features to identify tax havens and harmful preferential tax regimes and recommendations to combat these practices were proposed.

Harmful preferential tax regimes are mainly related to highly mobile activities as they can be shifted to any place offering low tax rates. These regimes also promote round-tripping of investments. The key elements to identify harmful preferential tax regimes include all the characteristics of tax havens mentioned above except the element of 'no substantial activities' and 'ring fenced': meaning that domestic markets are insulated from these harmful regimes. This may indicate adverse effects of the regimes can also affects countries offering these regimes. There are some additional factors that help in recognising harmful preferential tax regimes: failure to abide by transfer pricing rules, presence of secrecy provisions, access to extensive network of tax treaties and so on.

This report includes 19 recommendations which address the problem of tax competition (harmful tax practices). Coordinated efforts are more effective to curb harmful tax competition, being a global problem. The purpose of recommendations was to discourage countries which adopt harmful tax practices and offsetting benefits provided by same. Some of them are as follows:

- Access to banking information for tax purposes: eliminating all the obstructions to access that information by revising laws and regulations which offered an unfair advantage to those countries adopting harmful tax practices;

- Better use of exchange of information: by providing access to information obtained by one country with other country concerned and better use of information obtained through tax treaties;

- Following principles set out in guidelines on transfer pricing

- Set up Forum and guidelines to tackle and review harmful tax practices

- The Forum so created would make a list of tax havens on the basis of factors identified in report

- Persuade non-member countries to adopt the recommendations: they would be associated with the recommendations set out in the Report to eliminate harmful tax practices.

The OECD published another report, Towards Global tax Co-operation (2000), a progress report on the implementation of 1998 report. With regard to work on tax 
havens, the Forum had probed 47 jurisdictions to ascertain whether they potentially met the criteria of tax haven. It has published a list of 35 jurisdictions meeting the criteria of tax havens set out in 1998 report. However, this list does not include six jurisdictions that have made advance commitments and referred to as 'committed jurisdictions' to eliminate their harmful tax practices. OECD 2000 Report put pressure on the proposed tax havens to abide by the crucial norms of exchange of information and transparency. Subsequently after 2000 Report, number of 'committed jurisdictions' became 11 as 5 more jurisdictions committed to eliminate harmful tax practices. Also, one recognized tax haven made legislative and administrative changes to address the issue. The List of Uncooperative Tax Havens was also prepared in an attempt to make countries comply with norms.

The key principles of transparency and exchange of information for tax purposes to which tax haven countries must adhere were mainly focused on: developing a structure for the exchange of information on request for tax purposes between countries; strict confidentiality of information exchanged; availability of accounting, banking and ownership information.

The OECD currently has three lists on the basis of internationally agreed tax standard: a "white list" of countries implementing an agreed-upon standard, a "gray" list of countries that have committed to such a standard, and a "black" list of countries that have not committed. Tax information exchange agreements (TIEA) and other agreements have been signed by many countries to exclude their names from blacklist. Only one country (Nauru) existed on the gray list for tax havens in the year 2012. Most recent initiative of OECD is focused on Base Erosion and Profit Shifting (BEPS). Global Forum on Transparency and Exchange of Information for Tax purposes started reviewing countries on various criteria, under this initiative. The countries are rated compliant, largely compliant, partially compliant, or non-compliant.

\subsection{India and Tax Havens}

As per an estimate made by Global Financial Integrity (GFI), about $\$ 439.5$ billion illicitly flowed out of India between 2003 and 2012, most of which has apparently gone into tax havens. Out of this, $\$ 434.9$ billion outflow is due to fraudulent mis-invoicing of trade transactions only. India ranks $3^{\text {rd }}$ at the country rankings for highest illicit financial flows in the year 2012 after China ranked first and Russia second provided by GFI. The issue of unaccounted wealth has attracted a lot of attention in the recent past and has become a matter of political and national concern. The unaccounted wealth can be sent out of India through setting up of shell companies and depositing money in bank 
accounts in name of such companies in tax havens. This money cannot be taxed even on subsequent transactions since India has signed Double Taxation Avoidance Agreements (DTAA) with many such countries whereby income is taxed in either of the two countries and if such income is taxed in tax haven, then the rate of tax is minimal. This is all done because of the opacity in the global financial system.

India offer many tax breaks and tax holidays to new foreign investors to incentivise inward financial flows. Many investors round trip their investments to India from tax havens to take benefit of these tax incentives and DTAA of tax havens with India. For instance, Mauritius is endowed with key characteristics of quasi tax haven. The largest share i.e. around 35\% of total inflows of FDI in India comes from Mauritius. The foreign and domestic investors take advantage of Mauritius-India tax treaty, loopholes in capital gains taxation and lack of stringent information exchange agreements with Mauritius by routing their investments in India through Mauritius. Because of all this, India is losing its fair share of taxation. Therefore, India is negotiating for revisions in this age-old treaty with Mauritius.

A perfect example of offshore transfer of assets where no tax could be collected was Vodafone case of 2007. Hong-Kong based Hutchinson Telecommunication International Ltd. (HTIL) sold its 100\% share in CGP (Holdings) Ltd. based in Cayman Islands for consideration of USD 11.2 billion to Vodafone International Holdings B.V. (VIH) based in Netherlands. CGP through a number of intermediate companies hold $67 \%$ of Hutchison Essar Ltd., an Indian company. The actual sale appeared on paper simply as a transfer of shares in Cayman Islands shell company, sold by HTIL outside India to a company VIH outside India. No tax either capital gain or any other tax was levied in Cayman Islands (tax haven). The Income Tax Department alleged that this business deal leads to indirect transfer of assets situated in India and why tax was not withheld before making payment to HTIL. This offshore transaction denied India's ability to tax and Supreme Court judgment in 2012 also confirmed that there is absence of jurisdiction to tax. In this way many companies evade and avoid taxes using tax havens and leads to huge loss of tax revenues. This, in turn, hampers the development efforts of a country. In order to deal with this issue, domestic laws must be fool proof and all the loopholes in law must be covered. At the international level transparency, cooperation and consensus must be made to address the problem of tax havens.

\subsection{Conclusion}

In the recent years, tax havens have attracted increasing attention from the policymakers. This paper is an attempt to provide an overview of theoretical and 
empirical insights from literature on tax havens that analyses their determinants and impact on other countries. The current policy debates in taxation predominantly discuss tax havens, including tax competition and tax avoidance. The OECD initiative on harmful tax practices also emphases on tax havens and its use to evade taxes. Tax havens are used by MNC's to reduce or defer tax liabilities (to non-haven) nations, via strategic use of transfer pricing, debt and other means among affiliates.

The conventional 'negative view' of tax havens is demonstrated by Slemrod and Wilson (2006), depicting tax havens as 'parasitic' on high-tax countries tax bases. They conclude that presence of income shifting to tax havens forces them to reduce tax rates, intensifies tax competition, reduction in supply of public good and thus, ultimately reduces welfare of high tax countries. However, according to the emerging 'positive view', this need not be the case.

Under the world-wide taxation system (U.S.) foreign tax credit is given on the foreign tax paid on income earned in foreign country. As lower foreign tax credits are available, government benefits from income earned in tax havens. Thus, we can say that tax havens are more beneficial for multinationals under territorial taxation system. Under the tax exemption system (Germany) no complexity of deferral of tax liability is involved as it is easier to identify the impact of tax rate differences. Firm-specific marginal cost of income allocation negatively affects investments in tax havens. The studies under consideration depict characteristics of multinational firms (American) that use tax havens and growth patterns of haven and non-haven countries. The variables used in most of the studies are: sales, gross assets, plant, property and equipment (PPE), equity, income, employment, GDP, GNP. Large firms which are highly active abroad, greater foreign intra-firm trade and more technology-intensive are more likely to establish tax haven affiliates to relocate taxable income and defer tax liabilities. Tax havens exhibit rapid economic growth rate, and compare favourably with world average growth rate. Despite of offering tax incentives, public sectors of tax havens are comparable to the world. The economic activity in the non-haven countries is enhanced by presence of tax havens (Desai, Foley and Hines 2006, Hines 1990, 2005, 2010).

Tax havens attract large foreign direct investment, portfolio investment and employment. They also provide large agglomeration and spillover benefits to nearby countries especially developing countries. Tax havens compete for location and mobile capital. Countries nearer to tax havens exhibit more rapid economic growth (Blanco and Rogers 2011, 2013 and Hines 2010).

Most of the studies show the positive influence of tax havens on high-tax countries and elsewhere (Hines 1990, 2005, 2010, Keen 2001, Desai, Foley and Hines 2006, Hong and Smart 2007, Chu, Lai and Cheng 2013). Though existence of tax havens 
erode the tax bases of high-tax nations through tax planning (avoidance) and negatively affect government infrastructure expenditure but, largely the tax planning effect has positive influence on economic growths of the countries (Hong and Smart 2007, Chu, Lai and Cheng 2013). Tax planning (avoidance) may allow the multinational firms to reduce the marginal cost of capital or lowers their effective tax rates. Thus, multinationals can accumulate capital and keener to invest in non-haven country for any specified tax rate, and ultimately boosts growth. If the economy is inefficient (i.e. tax rates are too high), tax havens can improve social welfare. In spite of all this, tax rate under welfare maximisation is lower than growth maximisation tax rate.

However, claims about potentially positive effects of tax havens require further research if they are to be substantiated. Despite the fact that studies show positive impact of tax havens, they can harm the world economy in long run. Therefore, OECD and other various international organisations are working towards elimination of tax havens. With escalating pressure from international organisations like OECD and the G-20, tax havens may find it hard to maintain their carefree existence. Tax Information Exchange Agreements (TIEAs) between tax havens and other countries could take away tax havens' competitive advantage.

\section{References}

Blanco, L. R. \& Rogers C. L. (2011). Competition between tax havens: Does proximity matter? Pepperdine University, School of Public Policy Working Papers. Paper 23.

Blanco, L. R. \& Rogers C. L. (2014). Are tax havens good neighbours? FDI spillovers and developing countries. The Journal of Development Studies, 50:4,530-540. doi:10.1080/00220388.2013.874557

Chu, H. , Lai C. H. \& Cheng, C. C. (2014). Tax havens, growth, and welfare. Journal of Public Economic Theory. doi: 10.1111/jpet.12118

Desai, M. A., Foley, C. F. \& Hines, J. R. (2004). Economic effects of regional tax havens. NBER Working Paper no. 10806. doi: 10.3386/w10806

Dharmapala, D. \& Hines, J. R. (2006). Which countries become tax havens? NBER Working Paper no. 12802. doi: 10.3386/w12802

Ernst and Young. (2014) Worldwide Corporate Tax Guide. 
50 | VISION: Journal of Indian Taxation, Volume 2, Issue 1

Gumpert, A., Hines, J. R. \& Schnitzer, M. (2011). The use of tax havens in exemption regimes. NBER Working Paper no.17644. doi: 10.3386/w17644

Gravelle, J. G. (2015). Tax havens: International tax avoidance and evasion. Retrieved from https://www.fas.org/sgp/crs/misc/R40623.pdf

Hines, J. R. \& Rice, E. M. (1990). Fiscal Paradise: Foreign tax havens and American business. NBER Working Paper no.3477. doi: 10.3386/w3477

Hines, J. R. (2005). Do tax havens flourish? In Poterba, James (Ed.) Tax Policy and the Economy 19, (pp.65-100). Cambridge, MA: NBER \& MIT Press.

Hines, J. R. (2010). Treasure islands. Journal of Economic Perspectives, 24(4), 103-126.

Hong, Q. \& Smart, M. (2007). In praise of tax havens: International tax planning and foreign direct investment. CESifo Working Paper No. 1942.

Kar, D. \& Spanjers, J. Illicit Financial Flows from the Developing World: 2003-2012. Global Financial Integrity.

Keen, M. J. (2001). Preferential regimes can make tax competition less harmful. National Tax Journal, 54, 757-762.

OECD. (1998). Harmful tax competition: An emerging global issue. Paris: Organisation for Economic Co-operation and Development.

OECD. (2000). Towards global tax cooperation: Progress in identifying and eliminating harmful tax practices. Paris: Organisation for Economic Co-operation and Development.

OECD. (2001). The OECD'S project on harmful tax practices: The 2004 progress report. Paris: Organisation for Economic Co-operation and Development.

OECD. (2004). The OECD'S project on harmful tax practices: The 2004 progress report. Paris: Organisation for Economic Co-operation and Development.

Slemrod, J. \& Wilson, J. D. (2006). Tax competition with parasitic tax havens. NBER Working Paper no. 12225. doi: 10.3386/w12225 
United Nations Conference on Trade and Development (UNCTAD). (2013). World Investment Report.

\section{ANNEXURE-I}

\section{List of Tax Havens}

The tax havens tend to be concentrated in certain areas and locations close to large developed countries. There are 50 altogether. Following list contains the countries that appear on various lists, arranged by geographic location.

$\begin{array}{ll}\text { Caribbean/West Indies } & \text { Anguilla, Antigua and Barbuda, Aruba, Bahamas, } \\ & \text { Barbados, British Virgin Islands, Cayman Islands, } \\ & \text { Dominica, Grenada, Montserrat, Netherlands Antilles, } \\ & \text { St. Kitts and Nevis, St. Lucia, St. Vincent and } \\ & \text { Grenadines, Turks and Caicos, U.S. Virgin Islands } \\ \text { Central America } & \text { Belize, Costa Rica, Panama } \\ \text { Coast of East Asia } & \text { Hong Kong, Macau, Singapore } \\ \text { Europe/Mediterranean } & \text { Andorra, Channel Islands (Guernsey and Jersey), } \\ & \text { Cyprus, Gibraltar, Isle of Man, Ireland, Liechtenstein, } \\ \text { Indian Ocean } & \text { Luxembourg, Malta, Monaco, San Marino, Switzerland } \\ \text { Middle East } & \text { Maldives, Mauritius, Seychelles } \\ \text { North Atlantic } & \text { Bahrain, Jordan, Lebanon } \\ \text { Pacific, South Pacific } & \text { Bermuda } \\ \text { West Africa } & \text { Cook Islands, Marshall Islands, Samoa, Nauru, Niue, } \\ & \text { Tonga, Vanuatu }\end{array}$

Source: Tax Havens: International Tax Avoidance and Evasion (2015), Jane G. Gravelle 